\title{
Pengaruh Kinerja Keuangan, Struktur Modal dan Ukuran Perusahaan Terhadap Nilai Perusahaan Pada Perusahaan Farmasi yang Terdaftar pada BEI Tahun 2013-2017
}

\author{
Diana Susilowati ${ }^{1}$, H. M. Saiful Bahri ${ }^{2}$, Elok Dwi Vidiyastutik ${ }^{3}$, Tatik Amani ${ }^{4}$ \\ Program Studi Akuntansi, Universitas Panca Marga Probolinggo ${ }^{1234}$ \\ dianasusilowati23@gmail.com
}

\begin{abstract}
Abstrak
Pengaruh Kinerja Keuangan (ROA), Struktur Modal (DER) dan Ukuran Perusahaan (Total Assets) Terhadap Nilai Perusahaan Pada Perusahaan Farmasi Yang Terdaftar Pada BEI Tahun 2013-2017. Nilai perusahaan merupakan penilaian atau pandangan terhadap suatu perusahaan yang sering diasumsikan kepada nilai saham, sehingga pihak perusahaan berusaha untuk memaksimumkan nilai saham untuk meningkatkan nilai dalam perusahaannya. Penelitian ini bertujuan menemukan suatu bukti tentang pengaruh Kinerja Keuangan (ROA), Struktur Modal (DER) dan Ukuran Perusahaan (Total Assets) terhadap nilai perusahaan(PBV). Penelitian ini menggunakan sampel yaitu perusahaan farmasi terdaftar pada BEI tahun 2013-2017 dengan jumlah 7 perusahaan, menggunakan metode purposive sampling. Hasil penelitian menunjukkan dengan tingkat signifikansi $\alpha=0,05$ diketahui bahwa kinerja keuangan, struktur modal dan ukuran perusahaan dengan secara simultan berpengaruh terhadap nilai perusahaan yaitu dengan nilai $\mathrm{F}_{\text {hitung }}>\mathrm{F}_{\text {tabel }}$, hanya variabel ukuran perusahaan yang secara parsial tidak berpengaruh signifikan terhadap nilai perusahaan yaitu dengan nilai $t_{\text {hitung }}<\mathrm{t}_{\text {tabel }}$. Variabel struktur modal yang berpengaruh paling dominan terhadap nilai perusahaan, ditunjukkan dengan nilai Standardized Coefficients Beta 0,897 dengan $t_{\text {hitung }}(4,422)$ lebih besar dari lainnya.
\end{abstract}

\section{Kata kunci: ROA, DER, TOTAL ASSETS, PBV}

\begin{abstract}
Return On Assets (ROA), Debt to Equity Ratio (DER) and Total Assets on Corporate Values in Registered Pharmaceutical Companies in the Year 2013-2017. Firm value is an assessment or view of a company that is often assumed to be the value of shares so that the company seeks to max. the value of shares to increase the firm value. This research aims to find proof of the effect of Financial Performance (ROA), Capital Structure (DER) and Company Size (Total Assets) on firm value $(P B V)$. This study uses a sample of pharmaceutical companies listed on the Indonesian Stock Exchange in 2013-2017 with a total of 7 companies, using the purposive sampling method. The results showed with a significance level of $\alpha=0.05$, it was found that financial performance, capital structure, and company size simultaneously had an effect on the firm value with Fount $>$ Ftable, financial performance variables and capital structure partially had a sig. effect on firm value with count $>t$ table, firm size partially doesn't have an influence on the firm value. The capital structure variable that has the most dominant influence on firm value, is indicated by the value of Standardized Coefficients Beta 0.897 with count (4.422) greater than the other.
\end{abstract}

Keyword : ROA, DER, TOTAL ASSETS, PBV 


\section{PENDAHULUAN}

Perusahaan dibangun dengan mempunyai tujuan dengan harapan dicapai, tujuan perusahaan menjadi landasan pemikiran dan tujuan perusahaan juga menjadi acuan atau ukuran efektifitas operasional perusahaan. Terdapat dua macam tujuan perusahaan menurut jangka waktu yaitu tujuan jangka panjang serta tujuan jangka pendek, tujuan jangka panjang perusahaan yaitu mengoptimalkan nilai perusahaan yang didapatkan dengan cara meminiumkan biaya modal suatu perusahaan. Pengembangan perusahaan dalam upaya mengantisipasi adanya persaingan yang semakin tinggi seperti sekarang, akan selalu dilakukan baik oleh perusahaan terutama perusahaan go public. Banyaknya perusahaan-perusahaan industri dalam kondisi perekonomian saat ini yang membuat para pelaku bisnis berlomba-lomba melakukan inovasi dan strategi agar perusahaan terhindar dari kebangkrutan. Setiap perusahaan go public mempunyai beragam stakeholder, para stakeholder ini selalu melihat nilai perusahaan untuk kepentingan mereka.

Nilai perusahaan dapat dipengaruhi banyak faktor salah satunya adalah kinerja keuangan perusahaan. Menurut Fahmi (2016:190) "Turunnya nilai perusahaan bisa atau dapat mempengaruhi terhadap turunnya nilai saham pada perusahaan. Nilai Perusahaan diperoleh dari hasil kualitas kinerja suatu perusahaan khususnya kinerja keuangan (financial performance)." Pengukuran kinerja keuangan dalam suatu perusahaan dengan cara menggunakan alat ukur berupa rasio keuangan. Rasio keuangan memperlihatkan perubahan kondisi keuangan suatu perusahaan dan juga menunjukkan potensi perusahaan dalam mengelola kekayaan-kekayaan perusahaan dalam meningkatkan suatu nilai perusahaan. Biasanya nilai perusahaan yang dipengaruhi dengan kinerja keuangan terlihat dari salah satu rasio keuangannya yaitu rasio profitabilitas. ROA (Return On Asset) merupakan salah satu pengukur kinerja keuangan dari rasio profitabilitas. Selain dilihat dari segi kinerja keuangan, nilai perusahaan juga bisa dilihat dari struktur modal perusahaan.

Melakukan pengukuran struktur modal merupakan suatu hal yang penting karena dapat mengevaluasi risiko jangka panjang dan dapat meninjau tingkat penghasilan yang akan diperoleh dengan perusahaan selama melaksanakan kegiatan aktivitasnya. Berdasarkan teori struktur modal, jika posisi atau kedudukan struktur modal berada diatas target tertinggi struktur modalnya, maka setiap pertumbuhan hutang tersebut akan menurunkan suatu nilai perusahaan. Perbandingan total hutang suatu perusahaan dengan total ekuitas perusahaan disebut Struktur modal. Dalam mengukur struktur modal bisa menggunakan rasio likuiditas (DER). DER merupakan rasio yang dapat digunakan dalam mengukur hutang yang digunakan pihak perusahaan berbandingan dengan modal sendiri. Faktor yang menentukan nilai perusahaan selain kinerja keuangan dengan struktur modal yaitu ukuran perusahaan. Nilai perusahaan juga ada kaitannya dengan ukuran perusahaan, yang mana semakin besar suatu ukuran perusahaan maka semakin gampang perusahaan tersebut memperoleh kas, baik dari hasil pendapatan maupun dari pihak investor.

Tujuan dari penelitian ini adalah: 1) Untuk mengetahui Pengaruh Kinerja Keuangan (ROA), 2) Struktur Modal (DER) dan Ukuran Perusahaan(Total Assets) secara simultan terhadap Nilai Perusahaan Pada Perusahaan Farmasi yang Terdaftar Pada BEI Tahun 2013-2017. 3) Untuk mengetahui Pengaruh Kinerja Keuangan (ROA), Struktur Modal (DER) dan Ukuran Perusahaan (Total Assets) secara parsial terhadap Nilai Perusahaan Pada Perusahaan Farmasi yang Terdaftar Pada BEI Tahun 2013-2017. 4) Untuk mengetahui variabel yang berpengaruh dominan antara Kinerja Keuangan (ROA), Struktur Modal (DER) dan Ukuran Perusahaan (Total Assets) terhadap Nilai Perusahaan Pada Perusahaan Farmasi yang Terdaftar Pada BEI Tahun 2013-2017.

Analisis yang dilakukan dalam mengetahui sejauh mana suatu perusahaan telah menggunakan serta melaksanakan aturan-aturan dengan baik dan juga benar tentang hal-hal yang berkaitan dengan 
keuangan merupakan pengertian dari kinerja keuangan. Seperti halnya membuat laporan keuangan perusahaan yang sudah memenuhi standart serta ketentuan dalam SAK (Standart Akuntansi Keuangan) yang ditetapkan/ berlaku di Indonesia atau GAAP, dan lain-lain (Fahmi, 2017:2).

Kinerja keuangan merupakan salah satu analisis yang dilakukan dan disimpulkan oleh para stakeholder untuk melihat pelaksanaan dan pekerjaan seputar keuangan serta menilai suatu perusahaan dari sudut pandang pencatatan keuangan tersebut. Kinerja keuangan perusahaan menampakkan kemampuan perusahaan dari sudut pandang keuangan untuk memberikan keuntungan dari aset maupun ekuitas. Kinerja keuangan perusahaan merupakan prestasi kerja perusahaan. Nilai perusahaan yang seringkali dipengaruhi dengan kinerja keuangan dapat terlihat dalam salah satu rasio yaitu profitabilitas. Profitabilitas merupakan suatu rasio keuangan yang dapat menunjukkan keberhasilan suatu perusahaan memperoleh/ menghasilkan keuntungan. Return On Asset (ROA) adalah salah satu rasio keuangan profitabilitas yang merupakan salah satu pengukuran kinerja keuangan perusahaan.

$$
\mathrm{ROA}=\frac{\mathrm{EAT}}{\text { Total Assets }}
$$

Struktur modal adalah hal yang sangat berperan penting bagi pihak perusahaan karena struktur modal menyangkut kebijakan-kebijakan perusahaan dalam penggunaan sumber dana yang sangat menguntungkan. Dalam mendanai kebutuhan operasional, pihak perusahaan bisa memakai modal sendiri ataupun modal yang diperoleh dari utang (Ambarwati, 2010:1). Struktur Modal merupakan pembagian modal sendiri dengan hutang (sering kali hutang jangka panjang) perusahaan (Atmaja, 2008:2). Rasio Leverage juga dapat mempengaruhi nilai perusahaan, Debt to Equity Ratio merupakan rasio keuangan leverage yang berisi perbandingan antara dana yang didapat dari hutang dengan ekuitas seluruh perusahaan. Semakin rendah DER semakin aman perusahaan tersebut. Dari pengertian-pengertian tersebut dapat diketahui bahwa struktur modal dapat diukur dengan memakai salah satu rasio keuangan leverage yaitu Debt to Equity Ratio.

$$
\mathrm{DER}=\frac{\text { Total Utang (Debt) }}{\text { Ekuitas (Equity) }}
$$

Skala tentang besar kecilnya suatu perusahaan. Semakin besar suatu ukuran perusahaan maka perusahaan akan semakin mudah memperoleh sumber dana/modal baik dari yang bersifat internal atau dari eksternal disebut Ukuran perusahaan. Menurut Sudarsi (2002) dalam Prasetyo (2014) menjelaskan untuk menentukan suatu ukuran perusahaan dapat menggunakan rumus Size $=$ Ln of total aktiva.

Market value atau nilai pasar yang berasal dari hutang perusahaan dan ekuitas perusahaan merupakan pengertian Nilai perusahaan (Keown dkk, 2018:35). Nilai perusahaan merupakan pemikiran para investor terhadap tingkat kesuksesan perusahaan dalam kegiatan-kegiatan operasional perusahaan yang sering tercermin pada harga saham perusahaan. Untuk mengukur nilai perusahaan dapat menggunakan suatu rasio yaitu Price to book value, Menurut Hanafi (2015:131):

$$
\mathrm{PBV}=\frac{\text { Harga pasar saham per lembar }}{\text { Nilai buku modal saham per lembar }}
$$

Hipotesis merupakan jawaban-jawaban yang sementara yang didapatkan atau diperoleh dari rumusan masalah penelitian Sugiyono (2017:159). Berdasarkan penjelasan diatas tersebut, dapat dikumpulkan secara keseluruhan hipotesis yang akan di uji di penelitian ini, sebagai berikut: 
$\mathrm{H}_{1}$ : Diduga ada pengaruh pada variabel $\mathrm{X}_{1} \mathrm{X}_{2}$ dan $\mathrm{X}_{3}$ secara simultan terhadap Nilai Perusahaan (variabel Y) Pada Perusahaan Farmasi yang Terdaftar Pada BEI Tahun 2013-2017

$\mathrm{H}_{2}$ : Diduga ada pengaruh pada variabel $\mathrm{X}_{1}, \mathrm{X}_{2}$ dan $\mathrm{X}_{3}$ secara parsial terhadap Nilai Perusahaan (variabel Y) Pada Perusahaan Farmasi yang Terdaftar Pada BEI Tahun 2013-2017

$\mathrm{H}_{3}$ : Diduga variabel Ukuran Perusahaan sebagai variabel $\mathrm{X}_{3}$ berpengaruh dominan terhadap Nilai Perusahaan (variabel Y) pada Perusahaan Farmasi yang terdaftar pada BEI Tahun 2013-2017

\section{METODE PENELITIAN}

Penelitian ini menggunakan suatu pendekatan kuantitatif. Berdasarkan karakteristik masalah di penelitian ini, penelitian ini memiliki jenis hubungan kausal dimana peneliti ini terdiri dari dua jenis variabel yaitu variabel independen (variabel mempengaruhi atau variable bebas) dan variabel dependen (yang dipengaruhi atau variable terikat). Populasi didalam penelitian merupakan perusahaan farmasi yang tercatat/terdaftar dalam Bursa Efek Indonesia selama periode 2013-2017 dengan jumlah 10 perusahaan (www.idx.co.id). Dengan menggunakan kriteria tertentu dalam penentuan sampel maka terdapat 7 perusahaan farmasi yang memenuhi kriteria dan dapat dijadikan sampel.

\section{HASIL DAN PEMBAHASAN}

Jumlah atau total keseluruhan perusahaan farmasi yang telah terdaftar dalam BEI selama periode penelitian ini yaitu sebanyak 10 perusahaan. Metode penentuan sampel yang digunakan yaitu dengan purposive sampling. Berdasarkan kriteria yang sudah ditetapkan maka, terpilih 7 perusahaan farmasi yang bisa menjadi sampel dalam penelitian ini. Setelah melakukan pengujian asumsi klasik, data sampel perusahaan dinyatakan lolos 4 uji asumsi klasik.

Analisis regresi berganda akan dilakukan jika jumlah variabel independenya minimal dua variabel. Variabel terikat di penelitian ini adalah nilai perusahaan. Sedangkan variabel bebasnya adalah kinerja keuangan (ROA), struktur modal (DER) dan ukuran perusahaan (Total Aktiva). Hasil analisis ini (tabel 1) dapat diketahui sebagai berikut :

Tabel 1. Rangkuman Analisis Regresi Linier Berganda

\begin{tabular}{|c|c|c|c|c|c|c|}
\hline \multicolumn{7}{|c|}{ Coefficients $^{\mathrm{a}}$} \\
\hline & \multirow[b]{2}{*}{ Model } & \multicolumn{2}{|c|}{$\begin{array}{c}\text { Unstandardized } \\
\text { Coefficients }\end{array}$} & \multirow{2}{*}{$\begin{array}{c}\text { Standardized } \\
\text { Coefficients } \\
\text { Beta }\end{array}$} & \multirow[b]{2}{*}{$\mathbf{T}$} & \multirow[b]{2}{*}{ Sig. } \\
\hline & & B & $\begin{array}{l}\text { Std. } \\
\text { Error }\end{array}$ & & & \\
\hline \multirow[t]{4}{*}{1} & (Constant) & -26.955 & 20.426 & & -1.320 & .197 \\
\hline & Kinerja Keuangan & .505 & .189 & .550 & 2.663 & .012 \\
\hline & Struktur Modal & 14.554 & 3.291 & .897 & 4.422 & .000 \\
\hline & Ukuran Perusahaan & .655 & .725 & .130 & .904 & .373 \\
\hline & ependent Variable: & Perusahaa & & & & \\
\hline
\end{tabular}

Persamaan regresi berganda yang didapat berdasarkan Tabel diatas yaitu $\mathrm{Y}=-26,955+0,505 \mathrm{X} 1+$ $14,554 \mathrm{X} 2+0,655 \mathrm{X} 3$ 
Tabel 2. Hasil Pengujian Secara Simultan

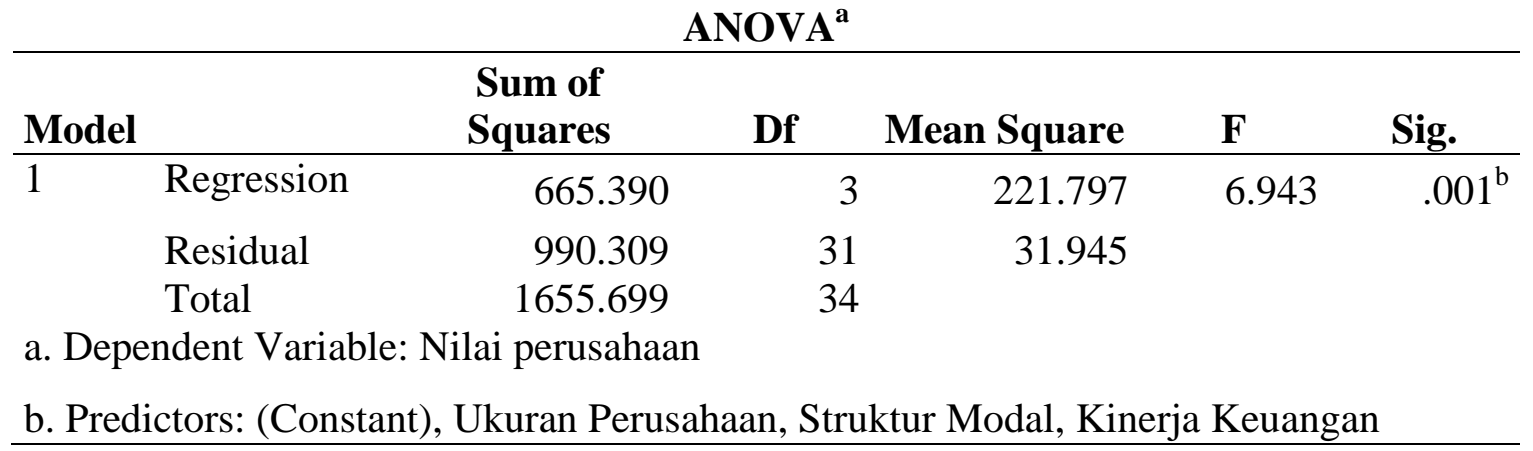

Hasil pengujian pada Tabel 2 menunjukkan nilai $F_{\text {hitung }}(6,943)>F_{\text {tabel }}(2,68)$ dihitung dengan menggunakan rumus $\mathrm{F}_{\text {tabel }}=\mathrm{F}(\mathrm{k} ; \mathrm{n}-\mathrm{k})=\mathrm{F}(4 ; 31)=2,68$. dan sig-value $=0,001<0,05$, sehingga hipotesis yang ditetapkan diterima yang berarti bahwa variabel bebas secara simultan berpengaruh terhadap nilai perusahaan(variabel terikat). Berdasarkan hasil uji $\mathrm{F}$, terbukti jika hipotesis yang ditetapkan dapat diterima.

Tabel 3. Hasil Pengujian Parsial

Coefficients $^{\mathrm{a}}$

\begin{tabular}{|c|c|c|c|c|c|c|}
\hline \multirow{2}{*}{\multicolumn{2}{|c|}{ Model }} & \multicolumn{2}{|c|}{$\begin{array}{l}\text { Unstandardized } \\
\text { Coefficients }\end{array}$} & \multirow{2}{*}{$\begin{array}{c}\text { Standardized } \\
\text { Coefficients } \\
\text { Beta }\end{array}$} & \multirow[b]{2}{*}{$\mathbf{T}$} & \multirow[b]{2}{*}{ Sig. } \\
\hline & & B & Std. Error & & & \\
\hline 1 & (Constant) & -26.955 & 20.426 & & -1.320 & .197 \\
\hline & Kinerja Keuangan & .505 & .189 & .550 & 2.663 & .012 \\
\hline & Struktur Modal & 14.554 & 3.291 & .897 & 4.422 & .000 \\
\hline & Ukuran Perusahaan & .655 & .725 & .130 & .904 & .373 \\
\hline
\end{tabular}

Pada Tabel 3 dapat dilihat uji signifikan parsial masing-masing variabel sebagai berikut: Variabel Kinerja Keuangan $\left(X_{1}\right)$ mempunyai $t_{\text {hitung }}(2,663)>t_{\text {tabel }}(2,0423)$. Dengan berikut bisa disimpulkan jika hipotesis yang ditetapkan diterima yang artinya secara parsial variabel Kinerja Keuangan (ROA) berpengaruh signifikan terhadap variabel Nilai Perusahaan. Hasil penelitian ini didukung penelitian yang sudah dilakukan Wardoyo dan Veronica (2013) yang menyatakan bahwa Return On Asset dan juga Return On Investment memiliki pengaruh secara signifikan terhadap variabel bebas yaitu Nilai Perusahaan.

Variabel Struktur Modal $\left(\mathrm{X}_{2}\right)$ mempunyai $t_{\text {hitung }}(4,422)>t_{\text {tabel }}(2,0423)$. Hal tersebut bisa diambil kesimpulan bahwa hipotesis yang ditetapkan diterima yang artinya variabel Struktur Modal (DER) secara parsial berpengaruh yang signifikan terhadap variabel Nilai Perusahaan(PBV). Hasil penelitian ini didukung penelitian yang dilakukan Dewi dan Wirajaya (2013) yang menghasilkan asumsi bahwa Struktur Modal sebagai variabel bebas secara parsial berpengaruh terhadap variabel Nilai Perusahaan. Hasil ini juga sejalan dengan pendapat Horne dan Wachoviz (2012:170) "Hal ini menunjukkan bahwa semakin besar presentase pendanaan yang disediakan oleh ekuitas pemegang saham, semakin besar jaminan perlindungan yang didapat oleh kreditur perusahaan”.

Variabel Ukuran Perusahaan $\left(\mathrm{X}_{3}\right)$ mempunyai $t_{\text {hitung }}(0,904)<t_{\text {tabel }}(2,0423)$. Dengan hal tersebut dapat disimpulkan jika hipotesis yang ditetapkan ditolak yang artinya variabel Ukuran Perusahaan (Total Asset) tidak berpengaruh signifikan secara parsial terhadap Nilai Perusahaan(PBV). Hasil 
penelitian ini didukung penelitian Mahatma dan Wirajaya (2013) yang menyatakan jika Ukuran Perusahaan tidak berpengaruh terhadap Nilai Perusahaan, namun bertolak belakang dengan penelitian Ta'dir Eko Prasetyo, Parengkuan T dan Ivone S. S. yang menyatakan ukuran perusahaan mempunyai pengaruh positif dan signifikan terhadap variabel bebas nilai perusahaan, Adanya ketidaksamaan hasil penelitian, membuat hasil penelitian ini menjadi anomali. Nilai perusahaan sering kali dikaitkan dengan investor dan harga saham. Pada penelitian ini dikatakan bahwa tidak adanya pengaruh ukuran perusahaan dengan nilai perusahaan. Hal ini dikarenakan investor membeli saham sebuah perusahaan tidak hanya ditinjau dari seberapa besar aktiva perusahaan namun juga dari sisi laporan keuangan, nama baik persusahaan dan juga kebijakan dividen.

Berdasarkan tabel 3 diatas pada kolom Standardized Coefficients Beta dapat diketahui variabel bebas yang dengan dominan berpengaruh terhadap variabel independen dapat diketahui yaitu variabel $\mathrm{X}_{1}$ Struktur Modal (DER) dengan nilai Standardized Coefficients Beta 0,897 dan nilai $\mathrm{t}_{\text {hitung }}(4,422)$ lebih besar dari nilai Standardized Coefficients Beta maupun $\mathrm{t}_{\text {hitung }}$ variabel bebas lainnya. Hipotesis yang telah dibangun oleh peneliti yaitu "Variabel Ukuran Perusahaan berpengaruh dominan terhadap Nilai Perusahaan pada Perusahaan Farmasi yang terdaftar pada BEI" menyatakan bahwa hipotesis tersebut ditolak. Berdasarkan hasil analisis perhitungan SPSS menunjukkan bahwa "Variabel Struktur Modal (DER) berpengaruh dominan terhadap Nilai Perusahaan pada Perusahaan Farmasi yang terdaftar pada BEI"

\section{KESIMPULAN}

Berdasarkan pembahasan dari hasil penelitian yang telah dijelaskan sebelumnya, maka peneliti dapat menarik kesimpulan, berdasarkan hasil dari spss, hasil uji F diketahui bahwa secara simultan Kinerja Keuangan (ROA), Struktur Modal (DER) dan Ukuran Perusahaan (Total Assets) berpengaruh terhadap Nilai Perusahaan pada perusahaan Farmasi yang Terdaftar Pada BEI Tahun 2013-2017. Dari hasil pengujian penelitian ini, secara parsial variabel Kinerja Keuangan (ROA), Struktur Modal (DER) berpengaruh signifikan terhadap variabel Nilai Perusahaan, sedangkan variabel Ukuran Perusahaan (Total Assets) terhadap variabel Nilai Perusahaan dinyatakan tidak berpengaruh pada Perusahaan Farmasi yang Terdaftar Pada BEI Tahun 2013-2017, dan dari ketiga variabel yang sangat berpengaruh atau memiliki pengaruh dominan terhadap Nilai Perusahaan adalah Struktur Modal (DER).

Berdasarkan kesimpulan diatas, terdapat beberapa saran yang bisa diberikan berdasarkan penelitian yang telah dilakukan: 1) Bagi pengguna laporan keuangan serta bagi investor atau calon investor hendaknya tidak mengandalkan Kinerja Keuangan (ROA), Struktur Modal (DER) dan Ukuran Perusahaan (Total Assets) saja dalam melihat suatu nilai perusahaan pada suatu perusahaan serta dalam mengambil keputusan pada suatu perusahaan, namun juga mempertimbangkan informasi keuangan lainnya yang belum merupakan variabel dalam penelitian ini, dan kondisi perekonomian saat ini. 2) Bagi perusahaan yang terdaftar diharapkan dapat lebih memanfaatkan sumber dayanya dan dapat lebih mengoptimalkan laba sehingga dapat menarik para investor dan juga dapat menaikkan harga saham dalam perusahaan. 3) Bagi peneliti selanjutnya hendaknya menambah jumlah sampel, waktu pengamatan, dan variabel yang digunakan agar penelitian selanjutnya dapat lebih akurat. 


\section{DAFTAR PUSTAKA}

Algifari. (2010). Statistika Deskriptif Plus untuk Ekonomi dan Bisnis. Yogyakarta: UPP STIM YKPN.

Ambarwati, S. D. A. (2010). Manajemen Keuangan Lanjut. Yogyakarta: Grahallmu.

Atmaja, L. S. (2008). Teori dan Praktik Manajemen Keuangan. Yogyakarta: Andi.

Dewi, A. S. M., \& Wirajaya, A. (2013). Pengaruh struktur modal, profitabilitas dan ukuran perusahaan pada nilai perusahaan. E-Jurnal Akuntansi Universitas Udayana, 4(2), 358-372.

Brigham, E. F. \& Houston, J. F. (2014). Dasar-dasar Manajemen Keuangan Buku 2. Edisi 11. Jakarta: Salemba Empat.

Desi, I \& Tumbel, A. L. (2014). Analisis kinerja keuangan pengaruhnya terhadap nilai perusahaan pada industri makanan dan minuman di BEI. Jurnal EMBA, 2(3), 1473-1482. Diunduh 18Oktober 2018.

EkaIndriyani. (2017). Pengaruh ukuran perusahaan dan profitabilitas terhadap nilai perusahaan. Jurnal Ilmu Akuntansi, 10(2), 2461-1190. Diunduh 27 November 2018.

Fahmi, I. (2017). Analisis Kinerja Keuangan. Bandung: Alfabeta.

Fahmi, I. (2016). Pengantar Manajemen Keuangan. Bandung: Alfabeta.

Ghozali, I. (2011). Aplikasi Analisis Multivariate dengan Program IBM SPSS19. Semarang: Universitas Diponegoro.

Ghozali, I. (2013). Aplikasi Analisis Multivariate dengan Program IBM SPSS23. Semarang: Universitas Diponegoro.

Hanafi, M. M. (2015). Manajemen Keuangan. Edisi Pertama. Yogyakarta:BPFE Yogyakarta.

Horne, J. C. V., \& Wachowicz, Jr. J. M. (2013). Prinsip-Prinsip Manajemen Keuangan. Edisi Tiga Belas. Jakarta: Salemba Empat.

Supranto, J. (2009). Statistika Teori dan Aplikasi. Edisi Ketujuh. Jakarta: Erlangga

Kasmir. (2016). Analisis Laporan Keuangan. Jakarta: Raja Grafindo Persada.

Keown, A. J., dkk. (2018). Manajemen Keuangan jilid 2. Edisi Kesepuluh. Jakarta: Indeks.

Pride, W. M., Hughes, R. J., dan Kapoor, J. R. (2014). Pengantar Bisnis (Introduction to Business). Edisi 11. Jakarta: Salemba Empat.

Rudianto. (2015). Akuntansi Manajemen Informasi Untuk Pengambilan Keputusan Strategis. Jakarta: Erlangga.

Solihin, I. (2014). Pengantar Bisnis. Jakarta: Erlangga.

Hasnawati, S. \& Sawir, A. (2015). Keputusan keuangan, ukuran perusahaan, struktur kepemilikan dan nilai perusahaan publik di Indonesia.Jurnal Manajemen dan Kewirausahaan, 17(12), 6575. Diunduh 27 November 2018.

Sudana, I. M. (2015). Manajemen Keuangan Perusahaan. Edisi Kedua. Jakarta: Erlangga.

Sugiyono. (2017). Metode Penelitian Kuantitatif, Kualitatif dan $R \&$ D. Bandung: Alfabeta.

Prasetyo, T. E., Tommy, P \& Saerang, I. S. (2014). Struktur modal, ukuran perusahaan dan risiko perusahaan terhadap nilai perusahaan otomotif yang terdaftar di BEI. Jurnal EMBA, 2(2), 879-889. Diunduh 17 November 2018.

Wardoyo \& Veronica, T. M. (2013). Pengaruh good corporate governance, corporate social responsibility dan kinerja keuangan terhadap nilai perusahaan. Jurnal Dinamika Manajemen, 4(2),132-149. Diunduh 29 November 2018.

www.idx.co.id/laporan.keuangan.perusahaan.farmasi/.Diunduh14 November 2018.

/harga.saham/. Diunduh 06Desember2018.

www.sahamok.com/harga.saham/. Diunduh 14November 2018. /saham.delisting/. Diunduh 14 November 2018. 